PRODUCTION

ENGINEERING ARCHIVES
2015,Vol. 7, No 2, pp 29-32

ISSN 2353-5156

ISSN 2353-7779 (print version)

(online version)

Article history: $\quad$ Received: 6.01.2015

\title{
Sustainability as an element of environmental management in companies
}

\begin{abstract}
Manuela Ingaldi ${ }^{1}$
${ }^{1}$ Institute of Production Engineering, Faculty of Management, Czestochowa University of Technology, Armii Krajowej 19B, 42-201 Czestochowa, Poland, +48 343250 399, e-mail: manuela@gazeta.pl

Abstract. The concept of sustainable development involves a properly and consciously shaped relationship between economic growth, care for the environment and life quality. The aim of this concept is to ensure the ability to provide the basic needs of both the present generation and also future generations. This concept introduced the need of environmental protection and most of all the change of environmental management strategies. One of the elements this strategy is waste minimisation that involves reducing the amount of waste produced in society and helps eliminate the generation of harmful and persistent wastes, supporting the efforts to promote a more sustainable society. The aim of the article is to introduce the definition of the concept of sustainability with regard to the environment. Waste minimisation in companies, which is connected with this concept, will be also presented.
\end{abstract}

Key words: sustainability, environment, environmental impact, waste minimisation

\section{Introduction}

All companies existing in the economy affect the surrounding natural environment. They use its resources during the production process, but also by this process they affect its conditions. However, according to Polish and EU legislation, these companies must take care of the environment and properly manage waste generated during the production process.

Waste management is a particular challenge for a company, mainly due to the costs connected with adaptation to the existing legislation. Not every company can afford such changes. Very often the companies prefer to pay the penalty because, from an economic point of view, it is lower than these costs. Very often, it also appears that investments in environmental protection repeatedly exceed the amount of any possible benefits that can be achieved. However, despite the situation on the market there are a lot of companies for which the natural environment is a priority (PustĚJovskÁ, P., JuRsovÁ, S., BrožOVÁ, S. 2012, INGALDI M., KOTUS M. 2014).

Sustainability is broadly defined as meeting the needs of the present generation without compromising the ability of future generations to meet their own needs. The term "sustainability" when applied institutionally within a university, is the development of a process or management system that helps to create a vibrant campus economy and high quality of life while respecting the need to sustain natural resources and protect the environment (CLOUGH G.W., Chameau J., Carmichael C. 2006).

The aim of the article is to introduce the definition of the concept of sustainability with regard to the environment. Waste minimisation in companies, which is connected with this concept, will be also presented. 


\section{Definition of sustainability}

The sustainable development of the Earth is a development that meets the basic needs of all human beings and which conserves, protects and restores the health and integrity of the Earth's ecosystem, without compromising the ability of future generations to meet their own needs and without going over the limits of long term capacity of the earth`s ecosystem (WORLD COMMISSION ON ENVIRONMENT AND DEVELOPMENT. "OUR COMMON FUTURE, CHAPTER 2: TOWARDS SUSTAINABLE DEVELOPMENT". 2011). This concept can be generally presented in the form of graph Fig. 1 .

This model recognises the importance of delivering sustainable economic value to shareholders by focusing on the bottom line profit that is generated. It also considers that if an enterprise is to be sustainable in the longer term, it needs to consider its performance in terms of the equivalent environmental and social "bottom lines".

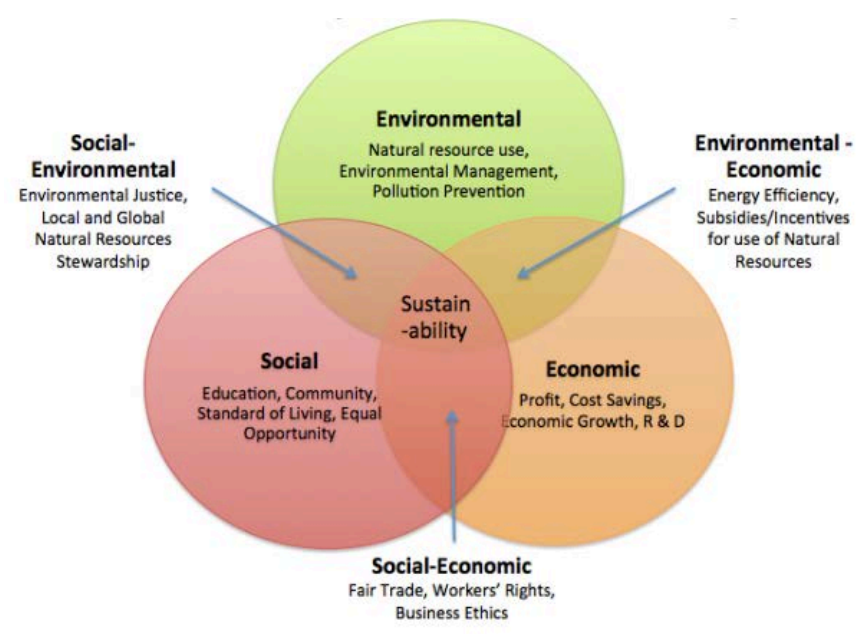

Fig. 1. The three spheres of sustainability.

Source: shanghaijill.wordpress.com/

In Poland the concept of sustainable development has gained constitutional status. It has been enshrined in Article 5 of the Constitution of Poland, and sustainable development was defined in the Environmental Protection Law. According to it, sustainable development is the socio-economic development in which there is the process integrating political, economic and social operations, with the preserving natural balance and the durability of basic natural processes, in order to guarantee the ability to meet basic needs of commu- nities and citizens of both the present and future generations (KONSTYTUCJA RZECZYPOSPOLITEJ POLSKIEJ).

On the basis of the concept of sustainable development, the UE law and laws of individual UE members in the field of environmental protection were adjusted.

\section{Definition of environment}

The simplest and, at the same time, most accurate definition of the environment is presented in the standard ISO 14001: 2005 Environmental Management System - Requirement with guidance for use. "Environment is surroundings in which an organization operates, including air, water, land, natural resources, flora, fauna, humans, and their interactions (surroundings in this context extend from within an organization to the global system)" (ISO 14001: 2005).

The companies operating within the said environment, affecting it, have led to its degradation. Therefore, to prevent further pollution, a number of laws, policies and strategies were introduced. The article briefly describes the most important rules.

Adapting to the constantly changing environmental regulations is especially noticeable for small and medium companies because of the costs associated with their production system adaptation. Therefore, environmental regulations must be largely treated as one of the groups of determinants that affect the functioning of these companies (SEROKA-STOLKA O. 2012).

\section{Environmental impact}

Each company, through manufacturing processes, produces a certain amount of waste, and at the same time in this way has an impact on the natural environment. The power of this impact depends mainly on the size of the company and the owned technologies.

There are more and more people in the world. This is due to the change of people's lifestyle, but mainly it is caused by the improvement of living conditions. Efficiently functioning economies in many countries, and at the same time people's lifestyle, allow a dignified life. However, all these elements do not remain indifferent to the environment. 
One of the initial attempts to express human impact mathematically was developed in the 1970s and is called the I PAT formula. This formulation attempts to explain human consumption in terms of three components: population numbers, levels of consumption (which it terms "affluence", although the usage is different), and impact per unit of resource use (which is termed "technology", because this impact depends on the technology used). The equation is expressed (Ehrlich P.R., Holden, J.P. 1974):

$$
\mathrm{I}=\mathrm{P} \times \mathrm{A} \times \mathrm{T}
$$

where:

$$
\begin{aligned}
& \text { I = Environmental impact, } \\
& \text { P = Population, } \\
& \text { A = Affluence, } \\
& \text { T = Technology. }
\end{aligned}
$$

\section{Waste minimisation}

Waste minimisation refers to the use of source reduction and/or environmentally sound recycling methods prior to energy recovery, treatment, or disposal of wastes. Waste minimisation does not include waste treatment, that is, any process designed to change the physical, chemical, or biological composition of waste streams. For example, compacting, neutralizing, diluting, and incineration are not typically considered waste minimization practices. EPA's preferred hierarchical approach to materials management includes source reduction, recycling, energy recovery, treatment, and finally, disposal (www.epa.gov/osw/hazard/wastemin/ minimize/faqs.htm).

Waste minimisation aims to eliminate waste before it is produced and reduce its quantity and toxicity. Prevention is the primary goal, followed by reuse, recycling, treatment and appropriate disposal (www.ehp.qld.gov.au/waste/minimisation/).

The policy and process to have the waste minimisation means to reduce the production of waste at societal and individual level. The wider part of the aim, which is called waste reduction, is often understood as waste hierarchy. This hierarchy included in the art. 4 of the Directive of the European Parliament and of the Council on waste and repealing certain directives, should apply as a priority order in law and policy relat- ing to both the prevention of bio-waste and its management (Fig. 2).

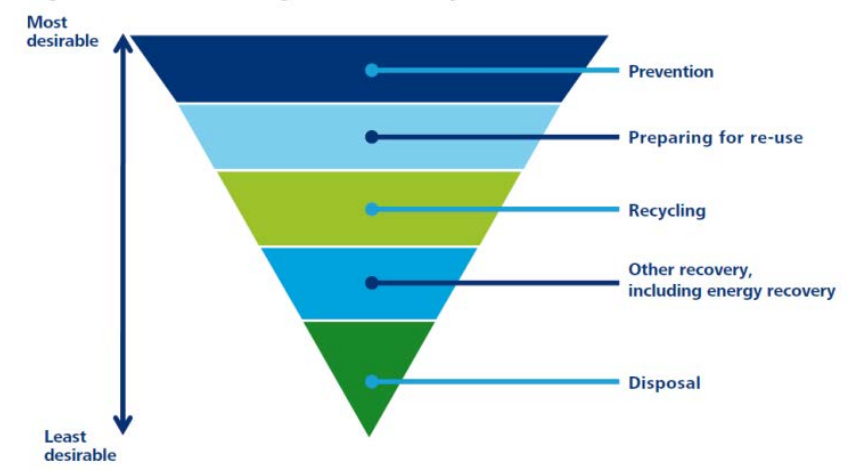

Fig. 2. Waste management hierarchy.

Source: Directive of the European Parliament and of the Council on waste and repealing certain directives)

Waste minimisation never comes free of cost and investment is required. This investment is remunerated by savings but it is a known fact that if a portion is processed for waste reduction then it is possible that another portion may get in to the excessive production of waste.

Source reduction and/or environmentally sound recycling, reuse, and reclamation practices have helped many organizations reduce (www.epa.gov/osw/hazard/ wastemin/minimize/faqs.htm):

- the quantity and toxicity of hazardous and solid waste generation,

- raw material and product losses,

- raw material purchase costs,

- waste management record keeping and paperwork burden,

- waste management costs,

- workplace accidents and worker exposure,

- compliance violations,

- environmental liability.

At the same time, waste minimisation can improve (www.epa.gov/osw/hazard/wastemin/minimize/faqs. htm):

- production efficiency,

- profits,

- good neighbour image,

- product quality,

- environmental performance. 


\section{Summary}

Nowadays, one of the main groups of determinants for companies are the rules and regulations on the environmental protection and waste management. The laws and regulations on the sphere relate to all Polish companies, but due to the costs associated with their compliance, these provisions are particularly felt by small and medium companies (INGALDI M., LESTYÁNSZKA ŠKŮRKOVÁ K. 2013; SYGUT P. 2013; KUŚMIERCZAK S., SVOBODOVÁ J. 2014).

Some companies, due to the costs of their own adaptation to those provisions, regard them as a necessary evil. However, the sustainable development concept clearly demonstrates the need of environmental protection, and thus the need for the company to bear the associated costs.

The reduction of the costs affect, in the final settlement, the larger profits made by companies. It must therefore be stressed that taking care of the environment is not only a need to invest, but also a long-term source of lower operating costs of the company and increasing achieved profits.

\section{References}

1. Clough, G.W., Chameau J., Carmichael C. 2006. Sustainability and the University. The Presidency, pp. 30-40.

2. DiRective of the EUROPEAN PARLIAMENT AND OF THE CoUnCIL 2008/98/WE of 19 November 2008 on waste and repealing certain directives. OJ.UE.L.08.312.3 of 22 November 2008.

3. EHRLICH P.R., Holden J.P. 1974. Human Population and the global environment. American Scientist 62(3), s. 282-292.

4. IngALDi M., KotUs M. 2014. End-of-Life Vehicles as the Resource of the Secondary Raw Materials. [In:] Analysis of Technology in Various Industries. Monography. Borkowski S., Ulewicz R. (Ed.). Oficyna Wydawnicza Stowarzyszenia Menedżerów Jakości i Produkcji, Częstochowa, p.95-106.

5. INGALDI M., LESTYÁNSZKA ŠKŮRKOVÁ K. 2013. Environmental management in Polish companies. [In:] Rusko Miroslav [Ed.] 2013: Management of Environment '2013. [Manažérstvo životného prostredia 2013]. -
Proceedings of the 13th International Scientific Conference, Bratislava, April 18 - 19, 2013. Strix: Žilina, Edition ESE-14, p. 16-19.

6. Iso 14001: 2005 Environmental Management System Requirement with guidance for use.

7. Konstytucja RZECZyPospolitej Polskiej.

8. KuŚMIERCZAK S., Svobodová J. 2014. Macroscopic quality evaluation of lacquered steel sheets. Production Egineering Archives. Vol. 2(1), p.26-30.

9. PustěJovskÁ, P., JuRsová, S., BrožovÁ, S. 2012. Technical-economic Prospects of Utilization of Alternative Ironmaking Techniques in Metallurgy. [In:] METAL 2012: 21TH Anniversary International Conference on Metallurgy and Materials: 23.-25. 5. 2012, Brno, Hotel Voroněž, Czech Republic [CD-ROM]. Ostrava: TANGER: May 2013. p. 1729-1733.

10. SeroKa-StolKa O. 2012. Czynniki implementacji dobrych praktyk środowiskowych $w$ matych $i$ średnich przedsiębiorstwach. Journal of Ecology and Health, pp. 98-103.

11. SHANGHAIJILL.WORDPRESS.COM/ AVAILABLE ON 27.06.2013.

12. SYGUT P. 2013. Process of quality improvement in the company producing building materials. Production Egineering Archives. Vol. 1(2), p.16-18.

13. WORLD COMMISSION ON ENVIRONMENT AND DEVELOPMENT. "our common future, Chapter 2: towards sustainable development". Un-documents.net. Retrieved 2011-09-28.

14. WWW.EHP.QLD.GOV.AU/WASTE/MINIMISATION/ AVAILABLE ON 12.03.2013.

15. WWW.EPA.GOV/OSW/HAZARD/WASTEMIN/MINIMIZE/FAQ S.HTM AVAILABLE ON 04.11.2013.

16. WWW.EPA.GOV/OSW/HAZARD/WASTEMIN/MINIMIZE/FAQ S.HTM AVAILABLE ON 09.04.2013. 